\title{
Pseudo-pneumothorax: skin fold is an excellent imitator
}

\author{
Kenichi Kishimoto, ${ }^{1}$ Takashi Watari, ${ }^{1}$ Yasuharu Tokuda ${ }^{2}$
}

'Postgraduate Clinical Training Center, Shimane University Hospital, Izumo city, Japan ${ }^{2}$ General Internal Medicine, Tsukuba University, Mito, Japan

\section{Correspondence to}

Professor Yasuharu Tokuda, yasuharu.tokuda@gmail.com

Accepted 19 July 2018

\section{DESCRIPTION}

A 79-year-old hospitalised woman underwent central venous catheterisation for high-calorie infusion. Chest radiography to check the position of the catheter showed a curvilinear line at the lateral zone of the right lung (figure 1A). We suspected pneumothorax and performed CT of the chest. However, it revealed the absence of pneumothorax; the curvilinear mimicked pneumothorax was revealed to be a skinfold (figure 1B).

The lateral margin of the skinfold artefact, caused by compression of flaccid back skin against the film, can be sharply outlined by a lucent line. ${ }^{1}$ This line is an edge enhancement phenomenon at the margin between objects with different contrast or luminance (Mach band effect). ${ }^{2}$ The area lateral to the skinfold artefact may be perceived darker than the hilar side because of the added density of the skinfold.

The lung marking sign is useful for differentiate pneumothorax from the other conditions, but in the emphysema and bullous disease, the lung marking can be vanished. Poor or no visualisation of normal lung and vascular tissues of the lateral side reinforced the similar appearance of pneumothorax. In a case with hubbly collapse of pneumothorax, the lung marking can be seen beyond the outside of the collapsed lung. ${ }^{3}$ In some situations,

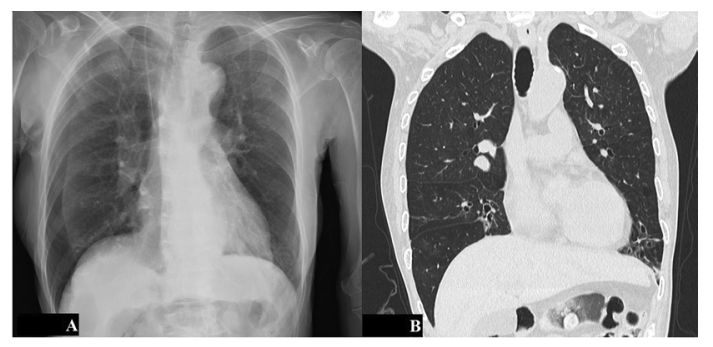

Figure 1 (A) Initial chest radiograph showed a curvilinear line at the right lateral zone of the right lung. (B) CT of the chest revealed the absence of pneumothorax.

\section{Patient's perspective}

If my chest $X$-ray findings have many points to learn, please use it as a study material.

\section{Learning points}

- Skinfold shadow is a frequent artefact on the anterior-posterior portable chest radiographs of patients in the critical care setting.

- Pneumothorax and skinfold might be difficult to differentiate on chest radiography. In those cases, lung ultrasonography or CT facilitators are helpful to make a correct diagnosis.

pneumothorax and skinfold might be difficult to differentiate on chest radiography. In those cases, lung ultrasonography or CT facilitators are helpful to make a correct diagnosis.

Acknowledgements The authors thank Professor Kazumichi Onigata of the Postgraduate Clinical Training Centre at Shimane University Hospital for his careful supervision of young physicians.

Contributors KK cared the patient. TW and YT supervised KK and revised the draft. All contributed in writing and editing and finally approved the manuscript.

Funding The authors have not declared a specific grant for this research from any funding agency in the public, commercial or not-for-profit sectors.

Competing interests None declared.

Patient consent Obtained.

Provenance and peer review Not commissioned; externally peer reviewed.

\section{REFERENCES}

1 Pérez-Girbés A, Paz-Maya S, Lemercier P. Skin fold resembling pneumothorax. Arch Bronconeumol 2015;51:417.

2 Fisher JK. Skin fold versus pneumothorax. AJR Am J Roentgenol 1978;130:791-2.

3 Kattea MO, Lababede O. Differentiating Pneumothorax from the Common Radiographic Skinfold Artifact. Ann Am Thorac Soc 2015;12:928-31. 
Copyright 2018 BMJ Publishing Group. All rights reserved. For permission to reuse any of this content visit http://group.bmj.com/group/rights-licensing/permissions.

BMJ Case Report Fellows may re-use this article for personal use and teaching without any further permission.

Become a Fellow of BMJ Case Reports today and you can:

- Submit as many cases as you like

- Enjoy fast sympathetic peer review and rapid publication of accepted articles

Access all the published articles

- Re-use any of the published material for personal use and teaching without further permission

For information on Institutional Fellowships contact consortiasales@bmjgroup.com

Visit casereports.bmj.com for more articles like this and to become a Fellow 